\title{
Financial Well-Being: Financial Ratio Analysis of Married Public Sector Workers in Malaysia
}

\author{
R. Zaimah ${ }^{1}$, Jariah Masud ${ }^{2}$, Sharifah Azizah Haron ${ }^{3}$, Mumtazah Othman ${ }^{3}$, Abd Hair Awang ${ }^{1} \&$ M. D. Sarmila ${ }^{1}$ \\ ${ }^{1}$ School of Social, Development and Environmental Studies, Faculty of Social Sciences and Humanities, \\ Universiti Kebangsaan Malaysia, Bangi, Malaysia \\ ${ }^{2}$ Institute of Gerontology, Universiti Putra Malaysia, Serdang, Malaysia \\ ${ }^{3}$ Department of Resource Management \& Consumer Studies, Faculty of Human Ecology, Universiti Putra \\ Malaysia, Serdang, Malaysia
}

Correspondence: R. Zaimah, School of Social, Development and Environmental Studies, Faculty of Social Sciences and Humanities, Universiti Kebangsaan Malaysia, 43600 Bangi, Selangor, Malaysia. Tel: 60-3-8921-5683, E-mail: zaimahr@ukm.my

\author{
Received: July 22, 2013 Accepted: September 1, 2013 Online Published: October 11, 2013 \\ doi:10.5539/ass.v9n14p1 URL: http://dx.doi.org/10.5539/ass.v9n14p1
}

\begin{abstract}
The purpose of this study is to explore the usefulness of two family financial ratio guidelines in assessing the financial well-being of married public sector workers in Malaysia. The ratios examined were savings and debt-payment. Data on 415 workers were gathered from the Financial Well-being of Workers of Dual-earner Family survey report in 2008. The findings showed most of the workers had a savings ratio of less than 10 percent. Meanwhile, more than half of the workers had debt-payments ratio of more than or equal to 20 percent. In addition, the workers fall into four categories, namely are A, B, C and D, of which level A is the best and level D the worst. Typically, most of the workers are in level D (42.2\%) and level B (30.1\%). In summary, the study revealed that the culture of saving among the workers was still at the unsatisfactorily level.
\end{abstract}

Keywords: financial well-being, married public sector workers, dual-earner families, objective measurement, saving ratio, debt-payment ratio

\section{Introduction}

The increasing cost of living, changing lifestyle, and consumption pattern among the Malaysian citizens especially among active workers need to be carefully examined to identify significant variables that influence their financial well-being (Malaysia, 2006). The level of financial well-being of a worker is significantly correlated with the worker's productivity. The increasing number of families that depend on two breadwinners, which is referred to as dual-earner family appears to be influencing the financial well-being of the individual workers (Sabitha, 2005; Ahmad 2008). Therefore further analysis on their level of financial well-being is very important.

Previous researchers have revealed that the problem with financial well-being of workers is influenced by factors such as unstable jobs, the increasing cost of living, the burden of debt, lack of financial knowledge and weak financial planning (Garman et al., 1996; Kim et al., 2003; Xiao et al., 2004). These situations led to negative impact on their daily living condition with lower productivity level, encounter with family relationship problems and also adversely influenced their health condition (Xiao et al., 2004).

Recently, the mass media have increased published news on individual problems associated with inadequate income and failure of financial management. For example, individuals who went bankrupt as a result of failure to manage their credit card usage (Berita Harian, 2007) indulging in excessive loans (Harian Metro, 2007) have been highlighted in the news media. As a consequence, suicide cases (Harian Metro, 2007) and family breakups and divorces (Harian Metro, 2007) were reported occur as a result of these financial difficulties. It has become a trend in recent years where more individuals have gone bankrupt (Bank Negara Malaysia, 2007 \& 2010).

Taking into consideration the recent trend mentioned earlier, this article aims to identify the level of financial well-being among public sector workers of dual-earner families in Malaysia. The levels of financial well-being were measured using objective measurement based on two financial ratios: savings ratio and debt-payment ratio. 
Financial ratio analysis can be useful in understanding the financial status of individuals and family, providing useful feedback to individuals and family concerning their current and future financial situations.

\section{Review of Literature}

\subsection{Objective Financial Well-being}

Financial well-being refers to the subjective perceptions and objective indicators of individuals' personal financial status. Objective indicators of financial circumstances include measures such as income, debt, savings and aspects of financial capability such as knowledge of financial products and services, planning ahead and living within the budget. Subjective perceptions include individuals' satisfaction with their current and future financial situation. Financial well-being describes the happiness and the satisfactory levels with the family's financial situations (Porter \& Garman, 1993; Kim et al., 2003).

Several studies have identified financial responses and financial practices as strategies of attaining satisfactorily level of financial well-being (Joo \& Garman, 1998; Kim et al., 2004; Porter \& Garman, 1993; Scannel, 1990). Furthermore, researches on financial distress and financial stress showed that financial management behavior is related to financial well-being (Kim et al., 2003 \& 2004; Xiao et al., 2004; Garman et al., 2005). In other words, financial distress and financial stress faced by an individual will contribute to the low financial well-being and vice versa.

Prior research used several approaches to measure financial well-being. One of the approaches used is objective measurement. Objective measurement is categorized as quantitative measurement through observation of the current financial performances. According to Porter and Garman (1993), objective measurement could be achieved through analysis on consumption of goods, asset acquisition, savings and social economic status. Additionally, demographic such as numbers of children, marital status, home ownerships, financial level and financial management practices can be used in the objective measurement scale.

Joo and Garman (1998) have used several types of objective measurement for example ability to pay loan, amount of emergency saving, monthly credit card payment, monthly loan payment, monthly life saving and pension fund (Greninger et al., 1996; Lytton et al., 1991). Furthermore, financial ratio is also used to measure levels of financial well-being (Greninger et al., 1996; Lytton et al., 1991). The ratio allows an analyst to measure and monitor one's financial status from time to time. Examples of financial ratio are basic liquidity ratio, asset to debt ratio, debt service to income ratio, debt payment to disposable income ratio, investment assets to total assets ratio and savings ratio (Garman \& Forgue, 2006).

In addition, financial well-being could also measure subjectively (Joo \& Garman, 1998; Porter \& Garman, 1993). Subjective measurement offers better explanation to understand the financial practices of a consumer (O'Neill et al., 1999). In comparison to subjective measurement, objective measurement does not describe the perception of the individual's financial situation (Porter \& Garman, 1993). An individual who is facing a similar financial situation as described by the objective measurement based on factors such as asset and income will probably have different perception of their financial well-being level (Kim et al., 2003).

\subsection{Financial Ratios - Savings Ratio and Debt-Payment Ratio}

Financial ratios are numerical calculations designed to simplify the process of assessing the financial condition (Garman \& Forgue, 2006; Kapoor et al., 2004). Several previous studies used the financial ratio to establish a benchmark of financial status (Baek \& DeVaney, 2004; DeVaney, 1994; Greninger et al., 1996; Prather, 1990). The findings of these studies showed that financial ratios are useful in measuring current financial strength and progress over time.

The savings ratio compares your dollars saved to your after-tax-income (Garman \& Forgue, 2006; Kapoor et al., 2004). A savings ratio measures an individual's capability in achieving financial aim through measurement of active saving. Moreover, the saving ratio also measures the percentage of active income for future consumption and not for current usage (Lytton et al., 1991). A good savings ratio will be in a range of at least 10 per cent (Greninger et al., 1996; Garman \& Forgue, 2006).

Debt-payment ratio divides the monthly disposable personal income into monthly debt repayment (excluding mortgage debt). Disposable personal income is the amount of income remaining after taxes and withholding for certain purposes such as insurance. The ratio shows the percentage of available money to pay back the loan (Lytton et al. 1991). A safety net for the ratio will be at least in range of 10 per cent where 11 to 15 per cent will lower the individual's financial flexibility and 16 to 20 per cent will show inability to pay or manage the loan repayment effectively (Greninger et al., 1996; Kapoor et al., 2004; Garman \& Forgue, 2006). 


\section{Methods}

The paper used the data from a research gathering data done in 2008 which was a study on the financial well-being among the workers of dual-earner family in the Malaysian's public sector. The sample of the study involved 415 married workers who have partners (either husband or wife) who also worked. A multi-stage sampling approach was used. First of all, six ministries were randomly selected from 28 ministries in the Federal Public Administration Office, Malaysia. Secondly, a list of married workers was gathered from the Human Resource Management in each of the ministries selected. A total number of 1,298 married workers whose partners also worked were selected from the list. Of these, 415 responded, attaining a response rate of 32 percent. Data were gathered using a questionnaire that was answered either by the husband or the wife themselves. Only descriptive analyses were referred to in the discussion.

Financial well-being is measured objectively using two financial ratios that are saving ratio and debt-payment ratio. Table 1 shows the formula and measurement of the savings ratio and debt-payment ratio. The saving ratio describes the ratio of savings for a period of one year. The debt-payment ratio describes the ratio of monthly loan payment excluding the housing loan.

Table 1. Financial ratios formula and measurement

\begin{tabular}{lll}
\hline & Formula & Measurement \\
\hline Savings ratio & Savings ratio = Annual & - Below $10 \%$ is a low savings \\
& savings/After-tax income & - Above and equal to $10 \%$ is a high savings \\
Debt-payment ratio & Debt-payment ratio = Annual & - Below 20\% is a low debt. \\
& debt repayments /Gross income & - Above and equal to 20\% is a high debt \\
\hline
\end{tabular}

\section{Findings and Discussion}

Table 2 shows the respondents' profile. A total of the 415 respondents participated in this study, of which 195 were males (47\%) and 220 females (53\%). The respondents' age ranged from 22 to 55 years old with an average age of 38 years old. The average length of marriage was 11 years and the average number of children was two. The education level attained by these respondents showed that 40.2 per cent of them were university graduates. In contrast, the rest of the respondents (59.8\%) were non university graduates. The average working period was 13 years and the average monthly income was RM3579.

Table 2. Respondents' profile

\begin{tabular}{lll}
\hline & Frequency/Mean & Percentage/S.D. \\
\hline Gender: & & \\
\multicolumn{1}{c}{ Female } & 195 & 47.0 \\
$\quad$ Male & 220 & 53.0 \\
Age & 38 & 9.45 \\
Length of marriage & 11 & 9.88 \\
Number of children & 2 & 1.77 \\
Education background: & & \\
$\quad$ Non University & 237 & 59.8 \\
$\quad$ University Graduates & 178 & 40.2 \\
Working period & 13 & 10.20 \\
Monthly income (RM) & 3579 & 2421.39 \\
\hline
\end{tabular}

Table 3 shows the distribution of both the savings and debt-payment ratio. More than 70 per cent of the respondents were at the low level of saving. As for the debt-payment ratio more than 50 per cent of the respondents were at the ratio that exceeded 20 per cent. The finding clearly shows that most of the respondents 
had higher debt-payment ratio than the savings ratio. In short, the finding showed an average saving ratio of eight per cent while the average debt-payment ratio is twenty three per cent. Theoretically, both ratios did not reach the values suggested by financial experts. The suggested saving ratio is 10 per cent while the debt-payment ratio should not exceed twenty per cent (Kapoor 2004; Garman \& Forgue 2006).

Table 3. Financial ratios - savings ratio and debt-payment ratio

\begin{tabular}{cll}
\hline Financial ratio & Frequency & Percentage \\
\hline Saving ratio (N1): & & \\
$<10 \%$ (Low) & 300 & 72.3 \\
$\geq 10 \%$ (High) & 115 & 27.7 \\
Debt-payment ratio (N2): & & \\
$<20 \%$ (Low) & 193 & 46.5 \\
$\geq 20 \%$ (High) & 222 & 53.5 \\
\hline
\end{tabular}

Based on the distribution of saving ratio and loan payment ratio listed in Table 3, the levels of financial well-being are clustered into four categories, namely A, B, C and D (Table 4). Level A is the best level and level $\mathrm{D}$ is the worst. Level A shows the number of respondents with N1 (high) and N2 (low). Level B refers to the respondents with $\mathrm{N} 1$ (low) and N2 (low). Level C refers to the respondents with N1 (high) and N2 (high). In contrast, level D refers to respondents with N1 (low) and N2 (high).

Table 4. Levels of financial well-being

\begin{tabular}{|c|c|c|c|c|}
\hline \multirow[t]{2}{*}{ Respondents' Profile } & $\begin{array}{l}A \\
n=68\end{array}$ & $\begin{array}{l}\mathrm{B} \\
\mathrm{n}=125\end{array}$ & $\begin{array}{l}\mathrm{C} \\
\mathrm{n}=47\end{array}$ & $\begin{array}{l}\mathrm{D} \\
\mathrm{n}=175\end{array}$ \\
\hline & \multicolumn{4}{|c|}{ Frequency (\%) / Average (S.D.) } \\
\hline \multicolumn{5}{|l|}{ Gender: } \\
\hline Male & $24(35.3 \%)$ & $56(44.8 \%)$ & $23(48.9 \%)$ & $92(52.6 \%)$ \\
\hline Female & $44(64.7 \%)$ & $69(55.2 \%)$ & $24(51.1 \%)$ & $83(47.4 \%)$ \\
\hline Age & $40(9.04)$ & $39(9.84)$ & $38(8.89)$ & $36(9.13)$ \\
\hline Length of married & $13(9.15)$ & $13(9.66)$ & $11(8.85)$ & $9(8.55)$ \\
\hline Numbers of children & $2(1.74)$ & $3(1.74)$ & $2(1.69)$ & $2(1.74)$ \\
\hline \multicolumn{5}{|l|}{ Education Background: } \\
\hline Non University & $35(51.5 \%)$ & $80(64.0 \%)$ & $23(48.9 \%)$ & $110(62.9 \%)$ \\
\hline University Graduate & $33(48.5 \%)$ & $45(36.0) \%$ & $24(51.1 \%)$ & $65(37.1 \%)$ \\
\hline Working Period & $15(9.78)$ & $15(10.66)$ & $12(10.00)$ & $11(9.78)$ \\
\hline
\end{tabular}

As shown in Table 4, 68 respondents (16.4\%) were found to be at level A which means they are at the best level of financial well-being. At this level, the respondents have savings ratio of at least and more than 10 per cent and debt-payment ratio of less than 20 per cent. Respondents at level A supposedly will not have a problem in possessing easy liquidity asset which can be used to pay monthly debt-payment. In this study, more female respondents $(64.7 \%)$ were at level A of financial well-being compared to the male respondents $(35.3 \%)$. These respondents were in the age range of 40 years with an average length of married of 13 years and the average working period of 15 years. This finding indicates that more mature workers have better financial well-being and this is consistent with the findings of Kim et al. (2003) and Baek and DeVaney (2004).

However, more respondents $(42.2 \%)$ in the study were at level $\mathrm{D}$ of financial well-being. The respondents at level $\mathrm{D}$ had a saving ratio of less than 10 per cent and debt-payment ratio of equal or more than 20 per cent. It is expected that those at level $\mathrm{D}$ would face problems in terms of having adequate cash to pay their monthly loan payment. More male respondents $(52.6 \%)$ compared to female respondents $(47.4 \%)$ were found to be at level D 
of financial well-being. Their average age group, length of marriage, and working period were 36 years old, 9 years and 11 years respectively. This finding indicates that young workers have a higher loan rate. In general, the workers at this age (especially men) have relatively greater family obligations, while their employment and income are still not stable.

Meanwhile among the total respondents, 30.1 per cent were at level B of financial well-being and 11.3 per cent at the level $\mathrm{C}$ of financial well-being. Those respondents in level $\mathrm{B}$ had low saving ratio and low debt-payment ratio, while those in level $\mathrm{C}$ had high saving ratio and high debt-payment ratio. The majority of the respondents at both level B (55.2\%) and C (51.1\%) were female respondents, of the age group between 38 to 39 years old, married between 11 to 13 years and had worked between 11 to 12 years. In general, those respondents who were older, being married for a longer period and also worked longer had better financial well-being from the other cohorts of the respondents. Previous studies have also confirmed these findings, such as those by Kim et al. (2003), Kim et al. (2004), Baek and DeVaney (2004), and Xiao et al. (2004).

\section{Conclusion}

This paper has outlined the financial ratio and levels of financial well-being among workers of dual-earner families in the public sector in Malaysia. The analysis has shown quantitatively the basic financial well-being of workers especially among workers of dual-earner families using saving ratio and debt-payment ratio. There were multiple levels of financial well-being ranging from level A which was the best level of financial well-being level B, C and D which were considered the weak levels of financial well-being. Based on the findings, it appears that the culture of saving among the workers was still at the unsatisfactorily level and did not reach the desired level. Additionally, many public sector workers did not cultivate effective saving habit in their lives. They were found to be more likely to spend more than what they earned.

In order to find better ways of promoting and motivating people to have good saving habit and effective spending habit, factors and mechanisms that contributed to the financial well-being should be well identified and studied. More comprehensive efforts and intervention measures should be taken in educating workers to balance their income with their spending capabilities. It is important because this study as well as prior research has proven that financial well-being influences the workers' productivity. Employers should take more initiatives to educate and assist their employees to have better financial planning management. In this way, there will be a 'win-win' situation where both employers and employees will receive benefits in terms of improved productivity and better quality of life.

\section{Acknowledgement}

Appreciation to Faculty of Social Science and Humanities, Universiti Kebangsaan Malaysia in funding this research SK-21-2007.

\section{References}

Ahmad, A. (2008). Direct and indirect effects of work-family conflict on job performance. The Journal of International Management Studies, 3(2), 176-180.

Baek, E., \& DeVaney, S. A. (2004). Assessing the baby boomers' financial wellness using financial ratios and a subjective measure. Family and Consumer Sciences Research Journal, 32, 321-348. http://dx.doi.org/10.1177/1077727X04263826

Bank Negara Malaysia. (2007). Buletin Perangkaan Bulanan, Jun 2007.

Cox, A., Hooker, H., Markwick, C., \& Reilly, P. (2009). Financial well-being in the workplace. Report 464, Institute for Employment. Retrieved from http://www.employment-studies.co.uk/sub/summary/php?id=464

DeVaney, S. A. (1994). The usefulness of financial ratios as predictors of household insolvency: two perspectives. Financial Counseling and Planning, 5, 5-24.

Garman et al. (2005). Final report: 30 million workers in America - one in four - are seriously financially distressed and dissatisfied causing negative impacts on individuals, families, and employers. Retrieved from http://www.orrgroup.com/document/FinalReport_30MillionWorkersSeriouslyFinanciallyDistressed.pdf

Garman, E. T., \& Forgue, R. E. (2006). Personal finance. New York: Houghton Mifflin Company.

Garman, E. T., Laech, I. E., \& Grable, J. E. (1996). The negative impact of employee poor personal financial behaviors on employers. Financial Counseling and Planning, 7, 157-168.

Gaya hidup mewah punca anak muda muflis. (2007). Berita Harian, 29 Mac. 
Greninger, S. A., Hampton, V. L., Kitt, K. A., \& Achacoso, J. A. (1996). Ratios and benchmarks for measuring the financial well-being of families and individuals. Financial Services Review, 5(1), 57-70. http://dx.doi.org/10.1016/S1057-0810(96)90027-X

Joo, S., \& Garman, E. T. (1998). Personal financial wellness may be the missing factor in understanding and reducing worker absenteeism. Personal Finances and Worker Productivity, 2(2), 172-182.

Kaki hutang ditipu along. (2007). Harian Metro, 22 November.

Kapoor, J. R., Dlabay, L. D., \& Hughes, R. J. (2004). Personal finance. New York: McGraw-Hill.

Kim, J., Garman, E. T., \& Sorhaindo, B. (2003). Relationships among credit counseling, financial well-being and health. Consumer Interests Annual, 49, 1-12.

Kim, J., Sorhaindo, B., \& Garman, E. T. (2004). Financial stress and work outcomes of credit counseling clients. Consumer Interest Annual, 50, 128-130.

Lelaki kecewa nekad terjun tingkat 10. (2007). Harian Metro, 5 Disember.

Lytton, R. H., Garman, E. T., \& Porter, N. M. (1991). How to use financial ratios when advising clients. Financial Counseling and Planning, 2, 3-23.

Malaysia. (2006). Rancangan Malaysia Kesembilan 2006-2010. Putrajaya: Jabatan Perdana Menteri, Malaysia.

Marican, S. (2005). Membentuk suasana kerja positif: aspek hubungan manusia dan persekitaran sosial. Kuala Lumpur: Utusan Publications \& Distributors.

Masalah ekonomi punca cerai. (2007). Harian Metro, 6 November.

O’Neill, B., Bristow, B., \& Brennan, P. (1999). Changing financial behavior: implication for family and consumer sciences professionals. Journal of family and Consumer Sciences, 91(4), 43-48.

Porter, N. M., \& Garman, E. T. (1993). Testing a conceptual model of financial well-being. Financial Counseling and Planning, 4, 135-165.

Prather, C. G. (1990). The ratio analysis technique applied to personal financial statements: development of household norms. Financial Counseling and Planning, 1, 53-69.

Scannel, E. (1990). Dairy farm families' financial management. Financial Counseling and Planning, 1, $133-146$.

Xiao, J. J., Sorhaindo, B., \& Garman, E. T. (2004). Financial behaviors of consumers in credit counseling. Consumer Interest Annual, 50, 131-133.

\section{Copyrights}

Copyright for this article is retained by the author(s), with first publication rights granted to the journal.

This is an open-access article distributed under the terms and conditions of the Creative Commons Attribution license (http://creativecommons.org/licenses/by/3.0/). 